\title{
Simple Additive Weighting for Decision Support Selection of Expedition Services
}

\author{
Suhar Janti \\ Bina Sarana Informatika University \\ Suharjanti.shj@bsi.ac.id
}

\author{
Mohammad Adriansyah \\ STMIK Nusa Mandiri, Jakarta, Indonesia \\ adriansy401@gmail.com
}

\author{
Ghofar Taufik \\ Bina Sarana Informatika University \\ ghofar.gft@bsi.ac.id
}

Submitted: Mar 6, 2020

Accepted: Mar 29, 2020

Published: Apr 3, 2020

\begin{abstract}
Freight forwarding services are increasingly developing and each delivery service provider competes to provide the best service, resulting in competition in terms of price and delivery time, in order to attract the attention of users of shipping services. The number of service providers with various types of packages offered by freight forwarding services, making users difficult in determining the right service provider. One way to overcome this problem is by the existence of a method that can provide recommendations as consideration for making appropriate decisions. This study aims to create a decision support system for the selection of goods delivery services by applying the Simple Additive Weighting method that can solve problems by comparing between shipping services. The results of this study are in the form of conclusion calculations that can be taken into consideration for decision making in choosing the most widely chosen freight forwarding services for students and getting the best results in decision making. The results of calculations using the Simple Additive Weighting method, the highest value based on time criteria is JNE YES with a value of 0.73 , based on price criteria is a vehicle with a value of 0.68 , based on the weight criteria is JNE YES with a value of 0.75 , while based on the volume criteria the highest value is a vehicle with a value of 0.70 .
\end{abstract}

Keywords-SAW; DSS; Expedition

\section{INTRODUCTION}

Freight forwarding services are increasingly developing and each delivery service provider is competing to provide the best service, resulting in competition in terms of price and delivery time, in order to attract the attention of users of shipping services. The number of service providers with various types of packages offered by freight forwarding services, makes it difficult for users to determine the right service provider with considerations such as shipping prices, delivery time, shipping weight and volume of goods sent.

To make the selection of shipping services in shipping goods can use the Simple Additive
Weighting (SAW) method. Decision support systems can be built as a tool for decision making in the selection of expedition services. In this study the criteria in selecting the expedition service are price, time, weight and volume. Many previous studies that use Simple Additive Weighting (SAW) which discusses the decision support system in conducting several alternatives with an assessment of existing criteria, including:

In his research (Prihatin, Retnasari, \& Fikri, 2019) it can be concluded that PT. Buana Estate Bukit Hambalang Villa Agrowisata in making decisions in choosing its best employees using Simple Additive Weighting (SAW). To facilitate decision making in 
evaluating employees must determine priorities, weights, or rankings based on the criteria given. Specified criteria include attendance, performance, discipline, attitude and neatness. This study got the results of the number of employees as many as 25 employees who were used as research samples, the employee named Pathurochman got the largest score of 0.95 and got the best employee title at PT. Buana Estate Bukit Hambalang Villa Agrotourism.

Other research (Ardhy \& Efendi, 2019) is giving rewards to employees using the Simple Additive Weighting method by using several criteria consisting of values of age, education, psychology, interviews, work experience and health. Based on the weighting calculation using the Simple Additive Weighting (SAW) method, the employee with the highest value is alternative A5 with a value of 85 and A6 with a value of 72.5 .

\section{LITERATUR REVIEW}

\section{A. Decision Support System}

Decision Support System is a computer-based information system that approaches to produce various alternative decisions to assist certain parties in dealing with problems using data and models (Nurjannah et al., 2015). Decision support systems are designed to support all stages of decision making ranging from identifying problems, selecting relevant data, and determining the approach used in the decision making process, to evaluating alternative choices (Hidayat, Widiyanto, \& Hasim, 2017). Decision making is the result of a selection process of various alternative actions that might be selected with certain mechanisms, with the aim of producing the best decision (Nurjannah et al., 2015)

Some characteristics contained in the decision support system are (Badrul, Rusdiansyah, \& Budihartanti, 2019) :

a. Can support an organization or company in making the decision process.

b. The existence of a human or interface (GUI) and humans as users hold the control in carrying out a process

c. Support decision making to discuss problems in a structured manner and support interactions for multiple decisions

d. Has a dialogue capacity to get information according to needs

e. Having an integrated subsystem in such a way can function as a system unity

f. Has two main components, namely data and mode

B. Multiple Attribute Decision Making
Multiple Attribute Decision Making (MADM) is a method used to find optimal alternatives from a number of alternatives with certain criteria. The essence of FMADM is to determine the weight value for each attribute, then proceed with a ranking process that will select alternatives that have been given (Daniati, 2015). Multiple Criteria Decision Making (MCDM) is a decision making method to determine the best alternative from a number of alternatives based on certain criteria. Criteria are usually in the form of measurements, rules or standards used in decision making (Kusumadewi \& Purnomo, 2013). According to Zimmermann, that based on its objectives, MCDM can be divided into two models namely, Multi Attribute Decision Making (MADM) and Multi Objective Decision Making (MODM) (Kusumadewi \& Purnomo, 2013).

\section{Proposed Method \\ Simple Additive Weighting}

One method of solving the MADM (Multiple Attribute Decision Making) problem is to use the Simple Additive Weighting method (Adianto, Arifin, \& Khairina, 2017). The basic concept of the SAW method is to find a weighted sum of the performance ratings for each alternative on all attributes (Manao et al., 2017). The SAW method requires the process of normalizing the decision matrix $(x)$ to a scale that can be compared with all available alternative ratings (Ikhmah \& Widawati, 2018).

In the Simple Additive Weighting (SAW) method, it is grouped into various criteria, then verification of fuzzy numbers in the form of crisp numbers so that the values will be carried out in the calculation process to find the best alternative (Gani, Kridalaksana, \& Arifin, 2019). In the Simple Additive Weighting (SAW) method of calculating alternative total scores, the assessment of each attribute must pass through normalization first. The process of normalizing the decision matrix (x) to which scale can be compared with all alternative assessments carried out by the following formula (Ketaren, 2016) :

$r_{i j}= \begin{cases}\frac{x_{i j}}{\max x_{i j}}, & \text { if } \mathrm{j} \text { is the profit attribute (benefit) } \\ \frac{\min x_{i j}}{x_{i j}}, & \text { if } \mathrm{j} \text { is the cost attribute (cost) }\end{cases}$

Information :

1. The symbol $r_{i j}$ is the normalized performance rating of alternative $\mathrm{Ai}$ on the attributes $\mathrm{Cj}, \mathrm{i}=1,2$, $\ldots, \mathrm{m}$ and $\mathrm{j}=1,2, \ldots, \mathrm{n}$. ( $\mathrm{m}$ and $\mathrm{n}$ are the many alternatives and criteria). 
2. The $x_{i j}$ symbol is the matching rating value on $\mathrm{Ai}$ and $\mathrm{Cj}$.

3. The $\max x_{i j}$ symbol is the largest value of all match rating values for each criterion.

4. Min $x_{i j}$ symbol is the smallest value of all match ratings for each criterion.

5. The profit attribute is if the greatest value in the attribute is the best value.

6. The cost attribute is if the smallest value in the attribute is the best value.

The preference value for each alternative $\left(V_{i}\right)$ is given as follows:

$V_{i}=\sum_{j=1}^{n} w_{j} r_{i j}$

Information :

1. The symbol $V_{i}$ is the ranking for each alternative

2. The symbol $n$ is the number (number) of alternatives

3 . The $w_{j}$ symbol is the weight value of each criterion 4. The $r_{i j}$ symbol is a normalized performance rating value

A greater value of $V_{i}$ indicates that the alternative $\mathrm{Ai}$ is preferred.

The alternative management steps that are used (in this case the decision to select shipping services), include (Surya \& Wahyu, 2020) :

1. Determine the alternative, namely Ai,

2. Determine the criteria that will be used as a reference in making decisions, namely $\mathrm{C}_{\mathrm{j}}$,

3. Determine the weight of preference or level of importance (W) of each criterion

$\mathrm{W}=\left[\mathrm{W}_{1}, \mathrm{~W}_{2}, \mathrm{~W}_{3}, \mathrm{~W}_{4}, \ldots, \mathrm{W}_{\mathrm{j}}\right]$

4. Give a rating of the suitability of each alternative on each criterion,

5. Make a decision matrix $(x)$ formed from the match rating table of each alternative to each criterion, the value of $\mathrm{x}$ every alternative (Ai) to each predetermined criterion $(\mathrm{Cj})$, where $\mathrm{i}=$ $1,2, \ldots, \mathrm{m}$ and $\mathrm{j}=1,2, \ldots, \mathrm{n}$

$$
=\left[\begin{array}{cccc}
x_{11} & x_{12} & \cdots & x_{1 n} \\
x_{21} & x_{22} & \cdots & x_{2 n} \\
\vdots & \vdots & & \vdots \\
x_{m 1} & x_{m 2} & \cdots & x_{m n}
\end{array}\right]
$$

6. Normalizing the decision matrix (x) to a scale that can be compared with all available alternative ratings.

$$
R_{i j=\frac{X_{i j}}{\operatorname{Max} X_{i j}}}
$$

7. The results of matrix normalization (Rij) form a normalized matrix $(\mathrm{R})$.

$$
R=\left[\begin{array}{cccc}
r_{11} & r_{12} & \cdots & r_{1 n} \\
r_{21} & r_{22} & \cdots & r_{2 n} \\
\vdots & \vdots & & \vdots \\
r_{m 1} & r_{m 2} & \cdots & r_{m n}
\end{array}\right]
$$

8. The end result of the preference value ( $\mathrm{Vi}$ ) is obtained from the sum of the multiplications of normalized matrix row elements (R) with preference weights (W) corresponding to the matrix column elements $(\mathrm{R})$.

9. The ranking process is obtained based on the alternative which has the largest to the lowest total value as the best alternative.

\section{RESULT AND DISCUSSION}

A. Requirement Analysis

The needs analysis in this case is divided into two parts, namely the input requirements analysis and the output needs analysis. The input needs analysis used is the following variables (criteria):
1. Price
2. Time
3. Weight

4. Volume

From these variables (criteria), the level of importance is determined based on the weighted value to the fuzzy numbers. Alternative match ratings for the following criteria:

TABLE I. FUZZY NUMBERS
\begin{tabular}{|l|c|}
\hline Fuzzy Number & Score \\
\hline Very Low & 1 \\
\hline Low & 2 \\
\hline Satis & 3 \\
\hline Hight & 4 \\
\hline Very High & 5 \\
\hline
\end{tabular}

Based on the criteria and rating match, alternative (Ai) to the criteria $(\mathrm{Cj})$, then the translation of the criteria weights $(\mathrm{Cj})$ are converted to Fuzzy numbers. As for the analysis of output needs in this study is an alternative that has the highest value compared to other value alternatives. What is meant by alternatives are the types of freight forwarding services mentioned earlier. 


\section{B. Data Processing and Calculation With SAW}

At this data processing stage, calculation or testing of the data that has been presented will be carried out using the Simple Additive Weighting (SAW) method which is carried out for data processing.

There are several steps to calculate the selection of goods shipping services using the simple additive weighting method, including:

1. Alternative Data Delivery Services

The first step is to determine the alternative Ai, here are the alternative data that will be used in the calculation.

TABLE II. ALTERNATIVE DATA

\begin{tabular}{|c|l|c|c|c|c|}
\hline No & Name & $\begin{array}{c}\text { Price } \\
(\text { IDR) }\end{array}$ & Time & $\begin{array}{c}\text { Weight } \\
(\text { Max })\end{array}$ & Volume \\
\hline 1 & JNE YES & 18,000 & $\begin{array}{c}\text { one } \\
\text { day }\end{array}$ & $150 \mathrm{Kg}$ & 6,000 \\
\hline 2 & $\begin{array}{l}\text { JNE } \\
\text { Reguler }\end{array}$ & 9,000 & $\begin{array}{c}1-2 \\
\text { days }\end{array}$ & $150 \mathrm{Kg}$ & 6,000 \\
\hline 3 & J\&T & 10,000 & $\begin{array}{c}1-3 \\
\text { days }\end{array}$ & $100 \mathrm{Kg}$ & 7,600 \\
\hline 4 & Wahana & 5,000 & $\begin{array}{c}1-4 \\
\text { days }\end{array}$ & $50 \mathrm{Kg}$ & 6,000 \\
\hline 5 & Tiki Reg & 9,000 & $\begin{array}{c}1-7 \\
\text { days }\end{array}$ & $75 \mathrm{Kg}$ & 6,000 \\
\hline 6 & Tiki Ons & 17,000 & $\begin{array}{c}1-1 \\
\text { days }\end{array}$ & $75 \mathrm{Kg}$ & 6,000 \\
\hline
\end{tabular}

\section{Criteria and Weight}

The second step determines the criteria that will be used as a reference in decision making $(\mathrm{Cj})$, including:

a. Price

Values and Weights for prices are shown below: TABLE III. PRICE

\begin{tabular}{|c|c|c|}
\hline $\begin{array}{c}\text { Price Range } \\
(\text { IDR) }\end{array}$ & Fuzzy Number & Score \\
\hline $1,000-5,000$ & Very Low & 1 \\
\hline $6,000-10,000$ & Low & 2 \\
\hline $11,000-15,000$ & Satis & 3 \\
\hline $16,000-20,000$ & Hight & 4 \\
\hline$>20,000$ & Very High & 5 \\
\hline
\end{tabular}

b. Time

Value and Weight for delivery time are shown: TABLE IV. TIME

\begin{tabular}{|c|c|c|}
\hline Time & Fuzzy Number & Score \\
\hline 1 day $(\max )$ & Very Low & 1 \\
\hline 2 days $(\max )$ & Low & 2 \\
\hline 3 days $(\max )$ & Satis & 3 \\
\hline 4 days $(\max )$ & Hight & 4 \\
\hline >5 days & Very High & 5 \\
\hline \multicolumn{3}{|c}{}
\end{tabular}

c. Weight

Value and Weight for weight are:

TABLE V. WEIGHT (MAX)

\begin{tabular}{|c|c|c|}
\hline Weight (Max) & Fuzzy Number & Score \\
\hline $1-25 \mathrm{~kg}$ & Very Low & 1 \\
\hline $26-50 \mathrm{~kg}$ & Low & 2 \\
\hline $51-100 \mathrm{~kg}$ & Satis & 3 \\
\hline $101-150 \mathrm{~kg}$ & Hight & 4 \\
\hline$>150 \mathrm{~kg}$ & Very High & 5 \\
\hline
\end{tabular}

d. Volume

Values and Weights for volumes are shown below:

TABLE VI. VOLUME

\begin{tabular}{|c|c|c|}
\hline Volume (cm) & Fuzzy Number & Score \\
\hline $1-2,500$ & Very Low & 1 \\
\hline $2,500-5,000$ & Low & 2 \\
\hline $5,000-7,500$ & Satis & 3 \\
\hline $7,500-1,000$ & Hight & 4 \\
\hline$>10,000$ & Very High & 5 \\
\hline
\end{tabular}

3. Weight Preferences (W)

The third step is to determine the preference weights or the importance level (W) of each criterion. The weight of this criterion that is used in selecting goods shipping services is as follows:

TABLE VII. IMPORTANCE (W)

\begin{tabular}{|c|c|c|}
\hline Criteria $\left(\mathbf{C}_{\mathbf{j}}\right)$ & Information & Weight $(\mathbf{W})$ \\
\hline$\left(\mathrm{C}_{1}\right)$ Price & Satis & $30 \%$ \\
\hline$\left(\mathrm{C}_{2}\right)$ Time & Hight & $40 \%$ \\
\hline$\left(\mathrm{C}_{3}\right)$ Weight & Very Low & $10 \%$ \\
\hline$\left(\mathrm{C}_{4}\right)$ Volume & Low & $20 \%$ \\
\hline
\end{tabular}

4. Match rating value of each alternative on each criterion

The fourth step is to determine the suitability rating of each alternative on each of the criteria specified above indicated:

TABLE VIII. ALTERNATIVE MATCH RATINGS

\begin{tabular}{|c|c|c|c|c|}
\hline $\begin{array}{c}\text { Alternative } \\
\text { (Delivery } \\
\text { service) }\end{array}$ & $\begin{array}{c}\text { Price } \\
\text { (C1) }\end{array}$ & $\begin{array}{c}\text { Time } \\
\text { (C2) }\end{array}$ & $\begin{array}{c}\text { Weight } \\
\text { (C3) }\end{array}$ & $\begin{array}{c}\text { Volume } \\
\text { (C4) }\end{array}$ \\
\hline A1 & 4 & 1 & 4 & 3 \\
\hline A2 & 2 & 2 & 4 & 3 \\
\hline A3 & 2 & 3 & 3 & 4 \\
\hline A4 & 1 & 4 & 2 & 3 \\
\hline A5 & 2 & 5 & 3 & 3 \\
\hline A6 & 4 & 1 & 3 & 3 \\
\hline
\end{tabular}




\section{Matrix of Decisions}

After alternative rating values for each criterion are determined, the fifth step is to make a decision matrix (x) formed from the match rating table of each alternative for each criterion, the value of $\mathrm{x}$ every alternative (Ai) for each predetermined criterion $(\mathrm{Cj})$.

$$
\left(\begin{array}{llll}
4 & 1 & 4 & 3 \\
2 & 2 & 4 & 3 \\
2 & 3 & 3 & 4 \\
1 & 4 & 2 & 3 \\
2 & 5 & 3 & 3 \\
4 & 1 & 3 & 3
\end{array}\right)
$$

6. Normalization of Decision Matrix (x)

The sixth step is to normalize the decision matrix (x) to a scale that can be compared with all existing alternative ratings. The value provided is a match value. For matrices $\mathrm{R}_{11}$ through $\mathrm{R}_{62}$ calculated using the formula:

$R_{i j}=\frac{\operatorname{Min} x_{i j}}{x_{i j}}$

With the example calculation as follows:

$R_{11}=\frac{\operatorname{Min}(4 ; 2 ; 2 ; 1 ; 2 ; 4)}{4}=\frac{1}{4}=0.25$

$R_{21}=\frac{\operatorname{Min}(4 ; 2 ; 2 ; 1 ; 2 ; 4)}{2}=\frac{1}{2}=0.50$

For matrices R13 through R64 calculated by the formula

$R_{i j}=\frac{x_{i j}}{\operatorname{Max} x_{i j}}$

With the example calculation as follows:

$R_{13}=\frac{4}{\operatorname{Max}(4 ; 4 ; 3 ; 2 ; 3 ; 3)}=\frac{4}{4}=1$

$R_{33}=\frac{3}{\operatorname{Max}(4 ; 4 ; 3 ; 2 ; 3 ; 3)}=\frac{3}{4}=0.75$

\section{Normalized Matrix (R)}

The results of matrix normalization (Rij) form a normalized matrix (R). And here is the normalized (R) matrix data.

$$
\left(\begin{array}{llll}
0.25 & 1.00 & 1.00 & 0.75 \\
0.50 & 0.50 & 1.00 & 0.75 \\
0.50 & 0.33 & 0.75 & 1.00 \\
1.00 & 0.25 & 0.50 & 0.75 \\
0.50 & 0.20 & 0.75 & 0.75 \\
0.25 & 1.00 & 0.75 & 0.75
\end{array}\right)
$$

\section{Value Preference (Vi)}

The next step is to calculate the final preference value (Vi) obtained from the calculation of the normalized matrix row element (R) with the preference weight $(\mathrm{W})$ corresponding to the matrix column element $(\mathrm{R})$ :

a. Time

Weight for time criteria is

TABLE IX. WEIGHTS(W) OF TIME

\begin{tabular}{|c|c|c|c|c|}
\hline \multicolumn{5}{|c|}{ Weights(W) of Time } \\
\hline $\begin{array}{c}\text { Price } \\
(\text { C1) }\end{array}$ & $\begin{array}{c}\text { Time } \\
(\text { C2) }\end{array}$ & $\begin{array}{c}\text { Weight } \\
(\mathbf{C 3})\end{array}$ & $\begin{array}{c}\text { Volume } \\
(\mathbf{C 4})\end{array}$ & Total \\
\hline $30 \%$ & $40 \%$ & $10 \%$ & $20 \%$ & 100 \\
\hline
\end{tabular}

The calculation is as follows:

$\mathrm{V} 1=[(0,3 \times 0,25)+(0,4 \times 1,00)+(0,1 \times 1,00)+(0,2$ $\mathrm{x} 0,75)]=0,73$

$\mathrm{V} 2=[(0,3 \times 0,50)+(0,4 \times 0,50)+(0,1 \times 1,00)+(0,2$ $\mathrm{x} 0,75)]=0,60$

$\mathrm{V} 3=[(0,3 \times 0,50)+(0,4 \times 0,33)+(0,1 \times 0,75)+(0,2$ $\mathrm{x} 1,00)]=0,56$

$\mathrm{V} 4=[(0,3 \times 1,00)+(0,4 \times 0,25)+(0,1 \times 0,50)+(0,2$ $\mathrm{x} 0,75)]=0,60$

$\mathrm{V} 5=[(0,3 \times 0,50)+(0,4 \times 0,20)+(0,1 \times 0,75)+(0,2$ $\mathrm{x} 0,75)]=0,46$

V6 $=[(0,3 \times 0,25)+(0,4 \times 1,00)+(0,1 \times 0,75)+(0,2$ $\mathrm{x} 0,75)]=0,70$

The following data are the results of the calculation of preference values presented in

\section{TABLE X. PREFERENCE VALUE

\begin{tabular}{|c|c|c|c|c|c|}
\hline \multirow{2}{*}{$\begin{array}{c}\text { Alternative } \\
\text { (Delivery } \\
\text { service) }\end{array}$} & \multicolumn{4}{|c|}{ Criterias } & \multirow[b]{2}{*}{ Outcome } \\
\hline & $\begin{array}{l}\text { Price } \\
\text { (C1) }\end{array}$ & $\begin{array}{l}\text { Time } \\
\text { (C2) }\end{array}$ & $\begin{array}{l}\text { Weight } \\
\text { (C3) }\end{array}$ & $\begin{array}{c}\begin{array}{c}\text { Volume } \\
\text { (C4) }\end{array} \\
\end{array}$ & \\
\hline A1 & 4 & 1 & 4 & 3 & 0,73 \\
\hline A2 & 2 & 2 & 4 & 3 & 0,60 \\
\hline A3 & 2 & 3 & 3 & 4 & 0,56 \\
\hline A4 & 1 & 4 & 2 & 3 & 0,60 \\
\hline A5 & 2 & 5 & 3 & 3 & 0,46 \\
\hline A6 & 4 & 1 & 3 & 3 & 0,70 \\
\hline
\end{tabular} CALCULATION RESULTS}

The biggest value is in V1, so alternative A1 (JNE YES) is the alternative chosen as the best alternative with the final result $=0.73$.

b. Price

Weights for prices can be seen as follows 
TABLE IX. WEIGHTS(W) OF PRICE

\begin{tabular}{|c|c|c|c|c|}
\hline \multicolumn{5}{|c|}{ Weights(W) of Price } \\
\hline $\begin{array}{c}\text { Price } \\
(\mathbf{C 1})\end{array}$ & $\begin{array}{c}\text { Time } \\
(\mathbf{C 2})\end{array}$ & $\begin{array}{c}\text { Weight } \\
(\mathbf{C 3})\end{array}$ & $\begin{array}{c}\text { Volume } \\
(\mathbf{C 4})\end{array}$ & Total \\
\hline $40 \%$ & $30 \%$ & $10 \%$ & $20 \%$ & 100 \\
\hline
\end{tabular}

The calculation is as follows:

$\mathrm{V} 1=[(0,4 \times 0,25)+(0,3 \times 1,00)+(0,1 \times 1,00)+(0,2$ $\mathrm{x} 0,75)]=0,65$

$\mathrm{V} 2=[(0,4 \times 0,50)+(0,3 \times 0,50)+(0,1 \times 1,00)+(0,2$ $\mathrm{x} 0,75)]=0,60$

$\mathrm{V} 3=[(0,4 \times 0,50)+(0,3 \times 0,33)+(0,1 \times 0,75)+(0,2$ $\mathrm{x} 1,00)]=0,58$

$\mathrm{V} 4=[(0,4 \times 1,00)+(0,3 \times 0,25)+(0,1 \times 0,50)+(0,2$ $\mathrm{x} 0,75)]=0,68$

$\mathrm{V} 5=[(0,3 \times 0,50)+(0,4 \times 0,20)+(0,1 \times 0,75)+(0,2$ $\mathrm{x} 0,75)]=0,49$

$\mathrm{V} 6=[(0,3 \times 0,25)+(0,4 \times 1,00)+(0,1 \times 0,75)+(0,2$ $\mathrm{x} 0,75)]=0,63$

The following data are the results of the calculation of preference values presented in

TABLE XI. PREFERENCE VALUE CALCULATION RESULTS

\begin{tabular}{|c|c|c|c|c|c|}
\hline \multirow{2}{*}{$\begin{array}{c}\text { Alternative } \\
\text { (Delivery } \\
\text { service) }\end{array}$} & \multicolumn{4}{|c|}{ Criterias } & \multirow{2}{*}{$\begin{array}{l}\text { Out } \\
\text { come }\end{array}$} \\
\hline & $\begin{array}{l}\text { Price } \\
\text { (C1) }\end{array}$ & $\begin{array}{l}\text { Time } \\
\text { (C2) }\end{array}$ & $\begin{array}{c}\text { Weight } \\
\text { (C3) }\end{array}$ & $\begin{array}{c}\text { Volume } \\
\text { (C4) }\end{array}$ & \\
\hline A1 & 4 & 1 & 4 & 3 & 0,65 \\
\hline $\mathrm{A} 2$ & 2 & 2 & 4 & 3 & 0,60 \\
\hline A3 & 2 & 3 & 3 & 4 & 0,55 \\
\hline A4 & 1 & 4 & 2 & 3 & 0,68 \\
\hline A5 & 2 & 5 & 3 & 3 & 0,49 \\
\hline A6 & 4 & 1 & 3 & 3 & 0,63 \\
\hline
\end{tabular}

The greatest value is in V4, so that alternative A4 (Wahana) is the alternative chosen as the best alternative with the final result $=0.68$.

c. Weight

Weight for weight criteria is

TABLE XII. WEIGHTS(W) OF WEIGHT

\begin{tabular}{|c|c|c|c|c|}
\hline \multicolumn{5}{|c|}{ Weights(W) of Weight } \\
\hline $\begin{array}{c}\text { Price } \\
(\text { C1 })\end{array}$ & $\begin{array}{c}\text { Time } \\
(\text { C2) }\end{array}$ & $\begin{array}{c}\text { Weight } \\
(\text { C3) }\end{array}$ & $\begin{array}{c}\text { Volume } \\
(\text { C4) }\end{array}$ & Total \\
\hline $30 \%$ & $20 \%$ & $40 \%$ & $10 \%$ & 100 \\
\hline
\end{tabular}

The calculation is $\mathrm{V} 1=[(0,3 \times 0,25)+(0,2 \times 1,00)+(0,4 \times 1,00)+(0,1$ $\mathrm{x} 0,75)]=0,75$

$$
\begin{aligned}
& \mathrm{V} 2=[(0,3 \times 0,50)+(0,2 \times 0,50)+(0,4 \times 1,00)+(0,1 \\
& \mathrm{x} 0,75)]=0,73 \\
& \mathrm{~V} 3=[(0,3 \times 0,50)+(0,2 \times 0,33)+(0,4 \times 0,75)+(0,1 \\
& \mathrm{x} 1,00)]=0,62 \\
& \mathrm{~V} 4=[(0,3 \times 1,00)+(0,2 \times 0,25)+(0,4 \times 0,50)+(0,1 \\
& \mathrm{x} 0,75)]=0,63 \\
& \mathrm{~V} 5=[(0,3 \times 0,50)+(0,2 \times 0,20)+(0,4 \times 0,75)+(0,1 \\
& \mathrm{x} 0,75)]=0,57 \\
& \mathrm{~V} 6=[(0,3 \times 0,25)+(0,2 \times 1,00)+(0,4 \times 0,75)+(0,1 \\
& \mathrm{x} 0,75)]=0,65
\end{aligned}
$$

\begin{tabular}{|c|c|c|c|c|c|}
\hline \multirow{2}{*}{$\begin{array}{l}\text { Alternative } \\
\text { (Delivery } \\
\text { service) }\end{array}$} & \multicolumn{4}{|c|}{ Criterias } & \multirow{2}{*}{$\begin{array}{c}\text { Out } \\
\text { come }\end{array}$} \\
\hline & $\begin{array}{l}\text { Price } \\
\text { (C1) }\end{array}$ & $\begin{array}{l}\text { Time } \\
\text { (C2) }\end{array}$ & $\begin{array}{c}\text { Weight } \\
\text { (C3) }\end{array}$ & $\begin{array}{c}\text { Volume } \\
\text { (C4) }\end{array}$ & \\
\hline A1 & 4 & 1 & 4 & 3 & 0,75 \\
\hline A2 & 2 & 2 & 4 & 3 & 0,73 \\
\hline A3 & 2 & 3 & 3 & 4 & 0,62 \\
\hline A4 & 1 & 4 & 2 & 3 & 0,63 \\
\hline A5 & 2 & 5 & 3 & 3 & 0,57 \\
\hline A6 & 4 & 1 & 3 & 3 & 0,65 \\
\hline
\end{tabular}

The following data are the results of the calculation of preference values presented in

TABLE XIII. PREFERENCE VALUE CALCULATION RESULTS

The biggest value is in V1, so alternative A1 (JNE YES) is the alternative chosen as the best alternative with the final result $=0.75$.

\section{d. Volume}

Weight for volume criteria is

TABLE XIV. WEIGHTS(W) OF VOLUME

\begin{tabular}{|c|c|c|c|c|}
\hline \multicolumn{5}{|c|}{ Weights(W) of Weight } \\
\hline $\begin{array}{c}\text { Price } \\
(\mathbf{C 1})\end{array}$ & $\begin{array}{c}\text { Time } \\
(\mathbf{C 2})\end{array}$ & $\begin{array}{c}\text { Weight } \\
(\mathbf{C 3})\end{array}$ & $\begin{array}{c}\text { Volume } \\
(\mathbf{C 4})\end{array}$ & Total \\
\hline $30 \%$ & $20 \%$ & $10 \%$ & $40 \%$ & 100 \\
\hline
\end{tabular}

The calculation is

$\mathrm{V} 1=[(0,3 \times 0,25)+(0,2 \times 1,00)+(0,1 \times 1,00)+(0,4$ $\mathrm{x} 0,75)]=0,68$

$\mathrm{V} 2=[(0,3 \times 0,50)+(0,2 \times 0,50)+(0,1 \times 1,00)+(0,4$ $\mathrm{x} 0,75)]=0,65$

$\mathrm{V} 3=[(0,3 \times 0,50)+(0,2 \times 0,33)+(0,1 \times 0,75)+(0,4$ $\mathrm{x} 1,00)]=0,69$

$\mathrm{V} 4=[(0,3 \times 1,00)+(0,2 \times 0,25)+(0,1 \times 0,50)+(0,4$ $\mathrm{x} 0,75)]=0,70$

$\mathrm{V} 5=[(0,3 \times 0,50)+(0,2 \times 0,20)+(0,1 \times 0,75)+(0,4$ $\mathrm{x} 0,75)]=0,57$

$\mathrm{V} 6=[(0,3 \times 0,25)+(0,2 \times 1,00)+(0,1 \times 0,75)+(0,4$ $\mathrm{x} 0,75)]=0,65$ 
The following data are the results of the calculation of preference values presented in

TABLE XV. PREFERENCE VALUE CALCULATION RESULTS

\begin{tabular}{|c|c|c|c|c|c|}
\hline \multirow{2}{*}{$\begin{array}{c}\text { Alternative } \\
\text { (Delivery } \\
\text { service) }\end{array}$} & \multicolumn{4}{|c|}{ Criterias } & \multirow{2}{*}{$\begin{array}{c}\text { Out } \\
\text { come }\end{array}$} \\
\hline & $\begin{array}{l}\text { Price } \\
\text { (C1) }\end{array}$ & $\begin{array}{l}\text { Time } \\
\text { (C2) }\end{array}$ & $\begin{array}{c}\text { Weight } \\
\text { (C3) }\end{array}$ & $\begin{array}{c}\text { Volume } \\
\text { (C4) }\end{array}$ & \\
\hline A1 & 4 & 1 & 4 & 3 & 0,68 \\
\hline $\mathrm{A} 2$ & 2 & 2 & 4 & 3 & 0,65 \\
\hline A3 & 2 & 3 & 3 & 4 & 0,69 \\
\hline A4 & 1 & 4 & 2 & 3 & 0,70 \\
\hline A5 & 2 & 5 & 3 & 3 & 0,57 \\
\hline A6 & 4 & 1 & 3 & 3 & 0,65 \\
\hline
\end{tabular}

The biggest value is in V4, so the A4 alternative (Wahana) is the alternative chosen as the best alternative with the final result $=0.70$.

\section{CONCLUSION AND SUGGESTION}

Simple Additive Weighting method can help produce the best alternative decisions in the decision of the choice of goods shipping services. And these alternatives are in accordance with the criteria that influence the selection of freight forwarding services.

From the process of calculating and ranking the alternatives obtained the highest value results which are the results required for consideration and recommendations for the user or in this case the users of goods delivery services. And the best alternative based on time is JNE YES, based on price is vehicle, based on weight is JNE YES and based on volume is vehicle.

The results of calculations using the Simple Additive Weighting method, the highest value based on time criteria is JNE YES with a value of 0.73 , based on price criteria is a vehicle with a value of 0.68 , based on the weight criteria is JNE YES with a value of 0.75 , while based on the volume criteria the highest value is a vehicle with a value of 0.70 .

\section{REFERENCES}

Adianto, T. R., Arifin, Z., \& Khairina, D. M. (2017). Sistem Pendukung Keputusan Pemilihan Rumah Tinggal Di Perumahan Menggunakan Metode Simple Additive Weighting (Saw) (Studi Kasus : Kota Samarinda). In Prosiding Seminar Ilmu Komputer dan Teknologi Informasi (Vol. 2, pp. 197-201).

Ardhy, F., \& Efendi, D. M. (2019). Pemberian Reward Terhadap Karyawan Terbaik Dengan
Menggunakan Metode Simple Additive Weighting ( SAW ). Jurnal Sistem Informasi \& Manajemen Basis Data (SIMADA), 2(2), 176181.

Badrul, M., Rusdiansyah, R., \& Budihartanti, C. (2019). Application of Simple Additive Weighting Method for Determination of Toddler Nutrition Status. SinkrOn, 4(1), 19. https://doi.org/10.33395/sinkron.v4i1.10145

Daniati, E. (2015). Sistem Pendukung Keputusan Pemilihan Kost Di Sekitar Kampus UNP Kediri Menggunak Metode Simple Additive Weighting (SAW). Seminar Nasional Teknologi Informasi Dan Multimedia 2015, (Pemilihan Kost), 2.2-145-2.2-150.

Gani, A., Kridalaksana, A. H., \& Arifin, Z. (2019). Analisa Perbandingan Metode Simple Additive Weighting (SAW) Dan Weight Product (WP) Dalam Pemilihan Kamera Mirrorless. Jurnal Ilmiah Ilmu Komputer, 14(2), 76-81.

Hidayat, T., Widiyanto, F., \& Hasim, Y. K. (2017). Rancang Bangun Decision Support System Pemilihan Guru Terbaik Menggunakan Metode Simple Additive Weighting (Saw)(Studi .... JUTIS Journal of Informatics Engineering, 5(1), 52-56. Retrieved from http://ejournal.unis.ac.id/index.php/jutis/article $/$ view/5

Ikhmah, \& Widawati, A. S. (2018). Sistem Pendukung Keputusan Pemilihan Tempat Wisata Purworejomenggunakan Metode Saw. Seminar Nasional Teknologi Informasi Dan Multimedia 2018, 91-96.

Ketaren, E. (2016). Utility Vectors To Fuzzy Preference Relation Dengan Metode Simple Additive Weighting ( SAW ) Dalam Penentuan Posisi Kerja Karyawan. SinkrOn, 1(1), 6-9. Retrieved from https://jurnal.polgan.ac.id/index.php/sinkron/ar ticle/view/2

Kusumadewi, S., \& Purnomo, H. (2013). Aplikasi Logika Fuzzy Untuk Pendukung Keputusan (2nd ed.). Yogyakarta: Graha Ilmu.

Manao, H., Nadeak, B., \& Zebua, T. (2017). Sistem Pendukung Keputusan Pemilihan Perumahan Dengan Metode Simple Additive Weighting (Saw). Media Informatika Budi Darma, 1(2), 49-53.

Nurjannah, N., Arifin, Z., \& Khairina, D. M. (2015). Sistem Pendukung Keputusan Pembelian Sepeda Motor Dengan Metode Weighted Product. Informatika Mulawarman: Jurnal Ilmiah Ilmu Komputer, 10(2), 20. https://doi.org/10.30872/jim.v10i2.186 
Prihatin, T., Retnasari, T., \& Fikri, M. (2019). A Determination of The Best Employees using Simple Additive Weighting (SAW) Method. SinkrOn, 4(1), 106. https://doi.org/10.33395/sinkron.v4i1.10169

Surya, C., \& Wahyu, A. (2020). Sistem Informasi Perhitungan Poin Pelanggaran Siswa Menggunakan Metode Simple Additive Weighting (SAW) (Studi Kasus Di SMK AsShofa Kabupaten Tasikmalaya). Jurnal TEKNOINFO, $14(1), \quad 59$. https://doi.org/10.33365/jti.v14i1.477 